\title{
Changes in Somatic Cell Count, Composition and Cytokine Levels in Milk from Cows with Mastitis Due to Mixed Infections
}

\author{
Tarik Safak $_{\oplus}^{1}$ \& Ali Risvanli ${ }^{2}$
}

\begin{abstract}
Background: Mastitis is a mammary gland inflammation that is very common worldwide, mostly caused by bacteria, and causes enormous economic losses. Many microorganisms cause this disease. The most common causes of mastitis by these microorganisms are Staphylococcus aureus (S. aureus), Escherichia coli (E. coli) and Streptococcus agalactiae ( $S$. agalactiae). The anti-inflammatory properties of transforming growth factor (TGF)- $\beta$ include: 1$)$ limiting interferon (IFN)- $\gamma$ production; 2) increasing the expression of the interleukine (IL)-1 receptor antagonist; 3 ) inhibiting macrophage production of chemokines, pro-inflammatory cytokines, nitric oxide, and reactive oxygen intermediates; and 4) increasing macrophage clearance of bacterial debris and damaged parenchymal cells. It is stated that cytokines and milk composition change in case of mastitis. In this study, it was aimed to reveal the changes in milk TGF- $\beta 1$ and Tumor necrosis factor (TNF)- $\alpha$ concentrations and milk composition in mixed infections caused by three pathogens causing mastitis.

Materials, Methods \& Results: In this study, milk samples from 90 cows were divided into 5 groups. Tumor necrosis factor (TNF)- $\alpha$ and TGF- $\beta 1$ concentrations and milk composition were determined in these milk samples. The California Mastitis Test (CMT) was applied to the cows included in the study and scoring was done. According to the CMT results of the milk samples taken, CMT(-) cows were included in group $1(\mathrm{n}=22)$. Those with the CMT $(+)$ were sent to the microbiology laboratory for analysis within $2 \mathrm{~h}$. After the bacteria was determined, combination groupings were formed. Group $2(\mathrm{n}=17)$, in which $S$. aureus and E. coli grew together, group $3(\mathrm{n}=21)$, in which $S$. aureus and $S$. agalactiae grew together, group $4(\mathrm{n}=8)$, in which $S$. agalactiae and $E$. coli grew together in milk samples, and milk samples without any bacterial growth in CMT $(+)$ formed group $5(n=22)$, respectively. Somatic cell count was measured with the DeLaval Cell Counter ${ }^{\circledR}$ (Cell Counter DCC) device. Mineral matter, fat, protein, lactose, electrical conductivity and specific gravity were measured in milk samples using Lactoscan Milk Analyzer (Milkotronic/EUROPE). Milk samples were then stored at $-80^{\circ} \mathrm{C}$ to measure TGF- $\beta 1$ and TNF- $\alpha$. Tumor necrosis factor- $\alpha$ and TGF- $\beta 1$ concentrations in milk samples were measured using ELISA kits (Sunred Biological Technology).

Discussion: Changes in milk TNF- $\alpha$ and TGF- $\beta 1$ concentration and milk composition were determined in milk samples with mastitis caused by mixed infection. The TNF- $\alpha$ concentration of group 4 was higher than the other groups. On the other hand, the highest concentration of TGF- $\beta 1$ was found in group 2 . While the number of somatic cells in group 1 was lower than in groups 2,3, and 4, there was no statistical difference between groups 1 and 5. The lowest milk fat ratio was found in group 1, and it was found to be statistically lower than groups 2, 3, and 4. While the rate of solid-non-fat of group 1 increased compared to groups 2 and 3, the highest protein ratio was found in groups 1 and 5. There was no difference between the 5 groups in terms of mineral matter ratios. While the specific gravity was highest in group 1 , there was no statistical difference between the other 4 groups. Overall, it was concluded that there was an increase in TNF- $\alpha$ and TGF- $\beta 1$ concentrations and a change in milk composition in samples with bacterial growth.
\end{abstract}

Keywords: bovine mastitis, cytokine, milk composition, raw milk, transforming growth factor. 
T. Safak \& A. Risvanli. 2021. Changes in Somatic Cell Count, Composition and Cytokine Levels in Milk from Cows with

\section{INTRODUCTION}

Mastitis is a costly disease for dairy farms worldwide. Microorganisms can cause mastitis individually as well as cause mixed infections. In both cases, the cow's immune system struggles to protect the udder tissue $[6,10,14,23]$.

The innate immune system detects the presence of foreign pathogens and creates an inflammatory response through cytokines such as interleukin (IL)-1 $\beta$, IL-8 and tumor necrosis factor (TNF)- $\alpha$, thus providing the first protection against mastitis $[23,27]$. On the other hand, the transforming growth factor (TGF)- $\beta$ is a well-known cytokine with its effect on cell growth and differentiation. TGF- $\beta$ has 3 known isoforms in mammals; TGF- $\beta 1$, TGF- $\beta 2$, and TGF- $\beta 3$ [22]. It has been reported that only TGF- $\beta 1$ and TGF- $\beta 2$ were detected in bovine milk $[8,12]$. TGF- $\beta$ plays an important role in mammary gland development and pathological processes associated with inflammation and host immune responses [2].

In addition to changing cytokine levels in case of mastitis [2], it is manifested by changes in milk protein, milk fat, solid-non-fat, lactose, mineral matter, and electrical conductivity $[13,17]$.

According to our knowledge, it is seen that milk composition and cytokine levels are investigated in cases of mastitis caused by a single bacteria. It has not been investigated how changes occur in the case of mixed infection. Therefore, this study, it was aimed to reveal the changes in milk TGF- $\beta 1$ and TNF- $\alpha$ concentrations and milk composition in mixed infections caused by 3 pathogens (Staphylococcus aureus, Streptococcus agalactiae and Escherichia coli), which are among the most important agents of mastitis.

\section{MATERIALS AND METHODS}

\section{Animals and sampling}

Clinically healthy, milked twice per day, multiparous (between parities 2 and 3) Simmental cows (n =90) from a private dairy farm were used in the study. California Mastitis Test (CMT) was administered to the cows included in the study. It was divided into CMT() and CMT (+) according to the score. Milk samples obtained from cows with negative 4 quarters according to the CMT result were included in the CMT (-) group, that is, group $1(\mathrm{n}=22)$. Milk samples obtained from cows with CMT (+) were delivered to the microbiology laboratory for analysis within $2 \mathrm{~h}$. Milk samples were bacteriologically tested according to National Mastitis Council (NMC) guidelines [11]. After being bacteriologically tested, milk samples of $S$. aureus, $E$. coli and $S$. agalactiae have grown in combination and were included in the study. Group $2(\mathrm{n}=17)$, in which $S$. aureus and E. coli grew together, group $3(\mathrm{n}=21)$, in which $S$. aureus and $S$. agalactiae grew together, group $4(\mathrm{n}=8)$, in which $S$. agalactiae and E. coli grew together in milk samples, and milk samples without any bacterial growth in CMT (+) formed group 5 ( $\mathrm{n}=$ $22)$, respectively. Milk samples in which only one of these bacteria or any bacteria other than these bacteria grew were excluded from the study. Milk samples were considered as contamination when three or more bacterial colonies were present in the milk samples and were excluded from the study.

\section{Somatic cell count}

Somatic cell count was performed on milk samples taken from cows belonging to the determined groups. It was measured in fresh milk by using the DeLaval Cell Counter ${ }^{\circledR}$ (Cell counter DCC) ${ }^{1}$ device according to the guidelines. After milk SCC analysis, milk samples were stored at $-80^{\circ} \mathrm{C}$ until TGF- $\beta 1$ and TNF- $\alpha$ analysis.

\section{Milk analysis}

In the milk samples, mineral matter (\%), fat $(\%)$, protein $(\%)$, solid-non-fat $(\%)$, lactose $(\%)$, electrical conductivity $(\mathrm{mS} / \mathrm{cm})$, and specific gravity $\left(\mathrm{kg} / \mathrm{m}^{3}\right)$ were measured by using a Lactoscan Milk Analyser ${ }^{2}$ device. Measurements were made in fresh milk and as described by Alam et al. [1].

\section{Cytokine analysis}

Species-specific commercial ELISA kits ${ }^{3}$ were used to determine the concentration of TNF- $\alpha$ and TGF- $\beta 1$ in milk. The ELISA procedure was performed by the guidelines and according to the literature [7]. The results were read by the ELISA reader $^{4}$ at $450 \mathrm{~nm}$.

\section{Statistical analysis}

The normality distribution of the cytokines (TNF- $\alpha$ and TGF- $\beta 1$ ), SCC, and milk composition (lactose, fat, solid-non-fat, protein, lactose, mineral matter, electrical conductivity, and specific gravity) were tested by using the visual (probability graphs and histogram) and Kolmogorov-Smirnov tests. There was 
no normal distribution for within-group values. So the Kruskal-Wallis test was used for inter-group comparison. The Corrected Bonferroni Mann-Whitney-U test was used in post-hoc analyses $(P<0.01)$.

\section{RESULTS}

A total of 90 milk samples from 90 selected cows were examined in the study. Somatic cell count of group 1 ( $47.81 \pm 5.79$ cells $/ \mathrm{mL})$ was low compared to group $2(749.64 \pm 281.33$ cells $/ \mathrm{mL}), 3(836.57 \pm$ 163.37 cells $/ \mathrm{mL})$, and $4(906.75 \pm 529.44$ cells $/ \mathrm{mL})[P$ $<0.01]$. For SCC, there was no statistical difference between group $5(396.45 \pm 58.54$ cells $/ \mathrm{mL})$ and group $1(47.81 \pm 5.79 \mathrm{cell} / \mathrm{mL})[P>0.01]$ (Table 1$)$.

The cytokine concentrations of the groups are presented in Table 2 . The concentration of TNF- $\alpha$ was highest in group $4(1861.62 \pm 162.40 \mathrm{ng} / \mathrm{L})$. TNF- $\alpha$ concentrations of groups $1(1193.86 \pm 69.26 \mathrm{ng} / \mathrm{L})$ and $5(1187.50 \pm 72.44 \mathrm{ng} / \mathrm{L})$ were found to be lower than groups $2(1578.82 \pm 89.22 \mathrm{ng} / \mathrm{L})$ and $3(1538.57 \pm$ $73.38 \mathrm{ng} / \mathrm{L})[P<0.01]$. Moreover, when groups 2 and 3 were compared, there was no statistical difference $(P>$ $0.01)$. On the other hand, the highest concentration of TGF- $\beta 1$ was found in group $2(52.08 \pm 4.09 \mathrm{ng} / \mathrm{mL})$. As in TNF- $\alpha$ concentration, there was no difference between the $1 \mathrm{st}(19.26 \pm 2.13 \mathrm{ng} / \mathrm{mL})$ and 5 th $(18.77$ $\pm 2.29 \mathrm{ng} / \mathrm{mL})$ groups $(P>0.01)$.
The results of milk composition and some chemical properties of the groups are given in Table 3. According to the table, the lowest milk fat ratio was found in group $1(3.20 \pm 0.16 \%)$ and it was found to be statistically lower than groups $2(5.27 \pm 0.67 \%), 3(5.15$ $\pm 0.33 \%)$, and $4(5.35 \pm 0.72 \%)[P<0.01]$. It was also determined that there was no difference between group $1(3.20 \pm 0.16 \%)$ and $5(4.17 \pm 0.34 \%)$ about milk fat ratio $(P>0.01)$. While the rate of solid-non-fat of group $1(10.49 \pm 0.07 \%)$ increased compared to groups $2(9.90 \pm 0.17 \%)$ and $3(9.95 \pm 0.15 \%)[P<0.01]$, it was found that there was no statistical difference with group $4(10.06 \pm 0.17 \%)$ and $5(10.24 \pm 0.15 \%)[P>$ $0.01]$. The highest protein ratio was found in groups 1 $(3.80 \pm 0.02 \%)$ and $5(3.66 \pm 0.06 \%)$ statistically $(P<$ $0.01)$. There was no difference between groups 2 ( 3.52 $\pm 0.06 \%), 3(3.46 \pm 0.04 \%)$, and $4(3.45 \pm 0.05 \%)$ with regard to milk protein ratios $(P>0.01)$. While the highest lactose ratio was found in group $1(5.76 \pm 0.03 \%)$, there was no statistical difference between the other 4 groups. There was no difference between the 5 groups in terms of mineral matter ratios $(P=0.427)$. While the specific gravity was highest in group 1 (1037.40 $\left.\pm 0.33 \mathrm{~kg} / \mathrm{m}^{3}\right)[P<0.01]$, no difference was found between the other 4 groups $(P>0.01)$. The electrical conductivity of milk was the lowest in group 1 (4.26 $\pm 0.02 \mathrm{mS} / \mathrm{cm})$. But, it was found in the highest value in group $3(4.60 \pm 0.04 \mathrm{mS} / \mathrm{cm})[P<0.01]$.

Table 1. Somatic cell count in milk from cows with mastitis due to mixed infections.

\begin{tabular}{|c|c|c|c|c|c|c|}
\hline & $\begin{array}{l}\text { Group } 1 \\
(\mathrm{n}=22)\end{array}$ & $\begin{array}{l}\text { Group } 2 \\
(\mathrm{n}=17)\end{array}$ & $\begin{array}{l}\text { Group } 3 \\
(\mathrm{n}=21)\end{array}$ & $\begin{array}{c}\text { Group } 4 \\
(\mathrm{n}=8)\end{array}$ & $\begin{array}{l}\text { Group } 5 \\
(\mathrm{n}=22)\end{array}$ & $P$ \\
\hline & $\overline{\mathrm{x}} \pm S_{\overline{\mathrm{X}}}$ & $\overline{\mathrm{x}} \pm S_{\overline{\mathrm{X}}}$ & $\overline{\mathrm{X}} \pm S_{\overline{\mathrm{X}}}$ & $\overline{\mathrm{x}} \pm S_{\overline{\mathrm{x}}}$ & $\overline{\mathrm{X}} \pm S_{\overline{\mathrm{X}}}$ & \\
\hline $\mathrm{SCC}\left(\times 10^{3}\right)($ cells $/ \mathrm{mL})$ & $47.81 \pm 5.79^{\mathrm{a}}$ & $749.64 \pm 281.33^{\mathrm{b}}$ & $836.57 \pm 163.37^{b}$ & $906.75 \pm 529.44^{b}$ & $396.45 \pm 58.54^{\mathrm{ab}}$ & * \\
\hline
\end{tabular}

Table 2. Concentration of cytokines in milk from cows with mastitis due to mixed infections.

\begin{tabular}{ccc}
\hline & TNF- $\alpha(\mathrm{ng} / \mathrm{L})$ & TGF- $\beta 1(\mathrm{ng} / \mathrm{mL})$ \\
\hline Group $1(\mathrm{n}=22)$ & $\overline{\mathrm{x}} \pm S_{\overline{\mathrm{x}}}$ & $\overline{\mathrm{x}} \pm S_{\overline{\mathrm{x}}}$ \\
\hline Group $2(\mathrm{n}=17)$ & $1193.86 \pm 69.26^{\mathrm{a}}$ & $19.26 \pm 2.13^{\mathrm{a}}$ \\
Group 3 $(\mathrm{n}=21)$ & $1578.82 \pm 89.22^{\mathrm{b}}$ & $52.08 \pm 4.09^{\mathrm{c}}$ \\
Group $4(\mathrm{n}=8)$ & $1538.57 \pm 73.38^{\mathrm{b}}$ & $39.81 \pm 3.40^{\mathrm{b}}$ \\
Group $5(\mathrm{n}=22)$ & $1861.62 \pm 162.40^{\mathrm{c}}$ & $42.44 \pm 7.46^{\mathrm{bc}}$ \\
\hline$P$ & $1187.50 \pm 72.44^{\mathrm{a}}$ & $18.77 \pm 2.29^{\mathrm{a}}$ \\
\hline
\end{tabular}

$\overline{\mathrm{a}, \mathrm{b}, \mathrm{c}}$ The difference between groups with different letters in the same column is statistically significant $(P<0.01)$. 
T. Safak \& A. Risvanli. 2021. Changes in Somatic Cell Count, Composition and Cytokine Levels in Milk from Cows with

Table 3. Milk composition from cows with mastitis due to mixed infections and same chemical properties between groups.

\begin{tabular}{|c|c|c|c|c|c|c|c|}
\hline & $\begin{array}{l}\text { Fat } \\
(\%)\end{array}$ & $\begin{array}{c}\text { Solid-non-fat } \\
(\%) \\
\end{array}$ & $\begin{array}{c}\text { Protein } \\
(\%)\end{array}$ & $\begin{array}{c}\text { Lactose } \\
(\%)\end{array}$ & $\begin{array}{c}\text { Mineral } \\
\text { matter }(\%)\end{array}$ & $\begin{array}{c}\text { Specific gravity } \\
\left(\mathrm{kg} / \mathrm{m}^{3}\right)\end{array}$ & $\begin{array}{c}\text { Electrical } \\
\text { conductivity }(\mathrm{mS} / \mathrm{cm})\end{array}$ \\
\hline & $\overline{\mathrm{x}} \pm S_{\overline{\mathrm{X}}}$ & $\overline{\mathrm{x}} \pm S_{\overline{\mathrm{x}}}$ & $\overline{\mathrm{x}} \pm S_{\overline{\mathrm{x}}}$ & $\overline{\mathrm{x}} \pm S_{\overline{\mathrm{x}}}$ & $\overline{\mathrm{x}} \pm S_{\overline{\mathrm{x}}}$ & $\overline{\mathrm{x}} \pm S_{\overline{\mathrm{x}}}$ & $\overline{\mathrm{x}} \pm S_{\overline{\mathrm{x}}}$ \\
\hline $\begin{array}{l}\text { Group } 1 \\
(\mathrm{n}=22)\end{array}$ & $3.20 \pm 0.16^{\mathrm{a}}$ & $10.49 \pm 0.07^{\mathrm{b}}$ & $3.80 \pm 0.02^{c}$ & $5.76 \pm 0.03^{\mathrm{b}}$ & $0.77 \pm 0.01$ & $1037.40 \pm 0.33^{\mathrm{b}}$ & $4.26 \pm 0.02^{\mathrm{a}}$ \\
\hline $\begin{array}{l}\text { Group } 2 \\
(\mathrm{n}=17)\end{array}$ & $5.27 \pm 0.67^{\mathrm{b}}$ & $9.90 \pm 0.17^{\mathrm{a}}$ & $3.52 \pm 0.06^{\mathrm{ab}}$ & $5.35 \pm 0.10^{\mathrm{a}}$ & $0.81 \pm 0.01$ & $1032.82 \pm 1.20^{\mathrm{a}}$ & $4.47 \pm 0.04^{\mathrm{bc}}$ \\
\hline $\begin{array}{l}\text { Group } 3 \\
(\mathrm{n}=21)\end{array}$ & $5.15 \pm 0.33^{\mathrm{b}}$ & $9.95 \pm 0.15^{\mathrm{a}}$ & $3.46 \pm 0.04^{\mathrm{a}}$ & $5.40 \pm 0.06^{\mathrm{a}}$ & $0.79 \pm 0.01$ & $1033.42 \pm 0.78^{\mathrm{a}}$ & $4.60 \pm 0.04^{c}$ \\
\hline $\begin{array}{l}\text { Group } 4 \\
(\mathrm{n}=8)\end{array}$ & $5.35 \pm 0.72^{b}$ & $10.06 \pm 0.17^{\mathrm{ab}}$ & $3.45 \pm 0.05^{\mathrm{a}}$ & $5.37 \pm 0.08^{\mathrm{a}}$ & $0.78 \pm 0.01$ & $1033.75 \pm 1.33^{\mathrm{a}}$ & $4.43 \pm 0.05^{\mathrm{b}}$ \\
\hline $\begin{array}{l}\text { Group } 5 \\
(\mathrm{n}=22)\end{array}$ & $4.17 \pm 0.34^{\mathrm{ab}}$ & $10.24 \pm 0.15^{\mathrm{ab}}$ & $3.66 \pm 0.06^{\mathrm{bc}}$ & $5.52 \pm 0.09^{\mathrm{ab}}$ & $0.80 \pm 0.01$ & $1034.04 \pm 0.69^{\mathrm{a}}$ & $4.46 \pm 0.06^{\mathrm{bc}}$ \\
\hline$P$ & .001 & .017 & .000 & .001 & .427 & .001 & .000 \\
\hline
\end{tabular}

a,b,c The difference between groups with different letters in the same column is statistically significant $(P<0.01)$.

\section{DISCUSSION}

Milk SCC increases due to the migration of neutrophils to the inflamed mammary tissue, that is, to the udder in case of mastitis [9]. In the study, SCC increased when there was bacterial growth in milk samples. Especially in milk samples from which $S$. agalactiae grew, SCC increased more. It was observed that there was no bacterial growth in milk samples and an increase in SCC. This can be interpreted as SCC being affected by non-infectious causes (such as age and breed of cattle, nutrition, number and period of lactation).

The innate immune response at the onset of mastitis is governed by the upregulation of proinflammatory cytokines, which initiates the mobilization of neutrophils to the site of infection [26]. Cytokines are known to play a role in inflammatory reactions. TNF- $\alpha$, a pro-inflammatory cytokine, has been reported to increase in both naturally occurring [25] and experimentally mastitis [3]. A higher TNF- $\alpha$ concentration was found in clinical and subclinical mastitis groups compared to healthy milk samples [24]. And even in clinical mastitis, TNF- $\alpha$ concentration increased more than in subclinical mastitis.

It has been reported that there is a positive correlation between the increase in clinical findings and TNF- $\alpha$ concentration in $E$. coli mastitis. In the same study, TNF- $\alpha$ was not detected in mastitis caused by $S$. aureus [4]. In the presented study, it was observed that the concentration of TNF- $\alpha$ in milk samples with bacterial growth was increased compared to healthy milk. TNF- $\alpha$ concentration in milk samples from which $S$. agalactiae and $E$. coli grew was found to be higher than the other groups.

It is stated that there is an increase in the concentration of TGF- $\alpha$ and TGF- $\beta 1$ during mastitis [8]. In this study, as in TNF- $\alpha$, TGF- $\beta 1$ concentration was found to be high in milk samples with bacterial growth. It was found to be much higher in milk samples from which $S$. aureus and E. coli grew. Contrary to the study of Shaheen et al. [24], Chockalingam et al. [8] reported that the concentration of TGF- $\beta 1$ increased with the aggravation of the infection.

Mastitis causes changes in the composition and chemical properties of milk. These changes affect the quality of milk and dairy products $[15,19]$. While it was stated that solid-non-fat and protein decreased in milk with mastitis caused by Staphylococcus xylosus and Staphylococcus warneri, it was claimed that there was no change in lactose and fat ratio [28]. In this study, the fat rate in healthy milk was found to be lower than in milk with mastitis. It was found that protein and solid-non-fat ratios were decreased in milk with mastitis caused by $S$. aureus, and the lactose ratio did not change due to mastitis [18]. Another study reported that there was no difference in lactose and protein content between healthy and subclinical mastitis milk [20]. In the 
presented study, solid-non-fat, protein, and lactose ratios were found to be higher in healthy milk than in milk samples with bacteria.

Kuplulu et al. [16] found the highest electrical conductivity $(7.53 \pm 0.22 \mathrm{mS} / \mathrm{cm})$ in milk with mastitis caused by $S$. aureus. Studies have shown that electrical conductivity increases in mastitis [5,13]. In our study, electrical conductivity was found to be lower in healthy milk samples compared to other groups. Also, it reached the highest level in milk samples where $S$. aureus and $S$. agalactiae grew together. There are researchers who state that electrical conductivity is higher when clinical mastitis occurs [20]. The same researchers also noted that the specific gravity of both clinical and subclinical mastitis did not change compared to healthy milk samples. In the presented study, the specific gravity value of healthy milk samples was found to be higher than the other groups. On the other hand, it is stated that the specific gravity is not affected in case of mastitis caused by different bacterial species $[21,28]$.

\section{CONCLUSION}

As a result, in this study, changes in milk composition and cytokine levels were determined in milk with mastitis due to mixed infections. When the changes in its composition were discussed with previous studies, it was seen that the changes in milk could not be standardized according to the bacterial species. Furthermore, due to the pleiotropic nature of cytokines/ growth factors in regulating mammary gland development and inflammation, it was concluded that they play a role in the innate immune responses to mastitis and maintenance of homeostasis.

\section{MANUFACTURERS}

${ }^{1}$ DeLaval International AB. Tumba, Sweden.

${ }^{2}$ Milkotronic Ltd. Nova Zagora, Bulgaria.

${ }^{3}$ Shanghai Sunred Biological Technology Co. Ltd. Shanghai, China. ${ }^{4}$ Bio Tek Instruments. Winooski, VT, USA.

Ethical approval. This study was approved by the Local Ethics Committee (FU-2018/98).

Declaration of interest. The authors report no conflicts of interest. The authors alone are responsible for the content and writing of paper.

\section{REFERENCES}

1 Alam S., Zaman M.A., Roy S., Ahmed J., Das M., Monzur K.C.Q.M., Deb Proma S. \& Popy F.Y. 2018. Evaluation of physio-chemical properties of locally produced raw milk in sylhet city corporation area, Bangladesh. Asian Food Science Journal. 3: 1-6. DOI: 10.9734/AFSJ/2018/42679

2 Bannerman D.D. 2009. Pathogen-dependent induction of cytokines and other soluble inflammatory mediators during intramammary infection of dairy cows. Journal of Animal Science. 87: 10-25. DOI: 10.2527/jas.2008-1187

3 Bannerman D.D., Chockalingam A., Paape M.J. \& Hope J.C. 2005. The bovine innate immune response during experimentally-induced Pseudomonas aeruginosa mastitis. Veterinary Immunology and Immunopathology. 107: 201215. DOI: $10.1016 /$ j.vetimm.2005.04.012

4 Bannerman D.D., Paape M.J., Lee J.W., Zhao X., Hope J.C. \& Rainard P. 2004. Escherichia coli and Staphylococcus aureus elicit differential innate immune responses following intramammary infection. Clinical and Diagnostic Laboratory Immunology. 11: 463-472. DOI: 10.1128/CDLI.11.3.463-472.2004

5 Boas D.F.V., Vercesi Filho A.E., Pereira M.A., Roma Jr. L.C. \& Faro L. 2017. Association between electrical conductivity and milk production traits in dairy Gyr cows. Journal of Applied Animal Research. 45(1): 227-233. DOI: 10.1080/09712119.2016.1150849

6 Burvenich C., Van Merris V., Mehrzad J., Diez-Fraile A. \& Duchateau L. 2003. Severity of Escherichia coli mastitis is mainly determined by cow factors. Veterinary Research. 34(5): 521-564. DOI: 10.1051/vetres:2003023

7 Can-Sahna K. \& Risvanli A. 2015. Th1/Th2 cytokine balance and SOCS3 levels of female offspring born from rats with gestational diabetes mellitus. Kafkas Üniversitesi Veteriner Fakültesi Dergisi. 21: 837-840. DOI: 10.9775/kvfd.2015.13723

8 Chockalingam A., Paape M.J. \& Bannerman D.D. 2005. Increased milk levels of Transforming Growth Factor- $\alpha$, $\beta 1$, and $\beta 2$ during Escherichia coli-induced mastitis. Journal of Dairy Science. 88(6): 1986-1993. DOI: 10.3168/jds. S0022-0302(05)72874-5

9 Fox L.K. 2009. Prevalence, incidence and risk factors of heifer mastitis. Veterinary Microbiology. 134(1-2): 82-88. DOI:10.1016/j.vetmic.2008.09.005 
T. Safak \& A. Risvanli. 2021. Changes in Somatic Cell Count, Composition and Cytokine Levels in Milk from Cows with

10 Halasa T., Huijps K., Osteras O. \& Hogeveen H. 2007. Economic effects of bovine mastitis and mastitis management: a review. The Veterinary Quarterly. 29: 18-31. DOI: 10.1080/01652176.2007.9695224

11 Hogan J.S., Gonzáles R.N., Harmon R.J., Nickerson C., Oliver P., Pankey W. \& Smith L. 1999. Harmon Laboratory Handbook on Bovine Mastitis. Madison: National Mastitis Council, pp.23-68.

12 Jin Y., Cox D.A., Knecht R., Raschdorf F. \& Cerletti N. 1991. Separation, purification, and sequence identification of TGF-beta1 and TGF-beta 2 from bovine milk. Journal of Protein Chemistry. 10: 565-575. DOI: 10.1007/BF01025484

13 Kasikci G., Cetin O., Bingol E.B. \& Gündüz M.C. 2012. Relations between electrical conductivity, somatic cell count, California mastitis test and some quality parameters in the diagnosis of subclinical mastitis in dairy cows. Turkish Journal of Veterinary and Animal Sciences. 36(1): 49-55. DOI: 10.3906/vet-1103-4

14 Keefe G. 2012. Update on control of Staphylococcus aureus and Streptococcus agalactiae for management of mastitis. The Veterinary Clinics of North America. Food Animal Practice. 28(2): 203-216. DOI: 10.1016/j.cvfa.2012.03.010

15 Kul E., Sahin A., Atasever S., Ugurlutepe E. \& Soydaner M. 2019. The effects of somatic cell count on milk yield and milk composition in Holstein cows. Veterinarski Arhiv. 89(2): 143-154. DOI: 10.24099/vet.arhiv.0168

16 Kuplulu S., Vural R., Izgur H., Kilicoglu C., Bastan A., Kaymaz M. \& Erdeger J. 1995. The use of milk checker in detecting subclinical mastitis. Ankara Universitesi Veteriner Fakültesi Dergisi. 42(3): 281-284

17 Lindmark-Mansson H., Bränning C., Aldén G. \& Paulsson M. 2006. Relationship between somatic cell count, individual leukocyte populations and milk components in bovine udder quarter milk. International Dairy Journal. 16(7): 717-727. DOI: 10.1016/j.idairyj.2005.07.003

18 Malek C.B., Barreiro J.R., Mestieri L., Porcionato M.F. \& Santos M.V. 2013. Effect of somatic cell count and mastitis pathogens on milk composition in Gyr cows. BMC Veterinary Research. 9(67): 1-7. DOI: 10.1186/1746-6148-9-67

19 Norberg E., Hogeveen H., Korsgaard I.R., Friggens N.C., Sloth K.H.M. \& Løvendahl P. 2004. Electrical conductivity of milk: ability to predict mastitis status. Journal of Dairy Science. 78(4): 1099-1107. DOI: 10.3168/jds. S0022-0302(04)73256-7

20 Panda B.S.K., Mohapatra S.K., Alhussien M.N. \& Dang A.K. 2019. Amount of milk neutrophil percentage and associated CD molecular changes on the compositional and technological properties of milk. The Open Biotechnology Journal. 13(1): 129-136.

21 Pecka-Kielb E., Vasil M., Zachwieja A., Zawadzki W., Elecko J., Zigo F., Illek J. \& Farkasová Z. 2016. An effect of mammary gland infection caused by Streptococcus uberis on composition and physicochemical changes of cows' milk. Polish Journal of Veterinary Sciences. 19: 49-55. DOI: 10.1515/pjvs-2016-0007

22 Plaut K., Dean A.J., Patnode T.A. \& Casey T.M. 2003. Effect of Transforming Growth Factor-beta (TGF- $\beta$ ) on mammary development. Journal of Dairy Science. 86: 16-27. DOI: 10.3168/jds.S0022-0302(03)74036-3

23 Rainard P. \& Riollet C. 2006. Innate immunity of the bovine mammary gland. Veterinary Research. 37: 369-400. DOI: $10.1051 /$ vetres:2006007

24 Shaheen T., Sheikh B.A., Rehman M.U., Muzami S., Bhat R.R., Hussain I., Bashir N., Rahman Mir M., Paray B.A. \& Dawood M.A.O. 2020. Investigations on cytokines and proteins in lactating cows with and without naturally occurring mastitis. Journal of King Saud University. 32(6): 2863-2867. DOI: 10.1016/j.jksus.2020.07.009

25 Slebodzinski A.B., Malinowski E. \& Lipczak W. 2002. Concentrations of triiodothyronine (T3), tumour necrosis factor- $\alpha$ (TNF- $\alpha$ ) and interleukin-6 (IL-6) in milk from healthy and naturally infected quarters of cows. Research in Veterinary Science. 72: 17-21. DOI: 10.1053/rvsc.2001.0514

26 Sordillo L.M. 2005. Factors affecting mammary gland immunity and mastitis susceptibility. Livestock Production Science. 98: 89-99. DOI: 10.1016/j.livprodsci.2005.10.017

27 Sordillo L.M. 2018. Mammary gland immunobiology and resistance to mastitis. The Veterinary Clinics of North America. Food Animal Practice. 34: 507-523. DOI: 10.1016/j.cvfa.2018.07.005

28 Vasil M., Pecka-Kielb E., Elecko J., Zachwieja A., Zawadzki W., Zigo F., Illek J. \& Farkasová Z. 2016. Effects of udder infections with Staphylococcus xylosus and Staphylococcus warneri on the composition and physicochemical changes in cows milk. Polish Journal of Veterinary Sciences. 19(4): 841-848. DOI: 10.1515/pjvs-2016-0105 